\title{
THE IMPLEMENTATION OF PROBLEM BASED LEARNING (PBL) MODEL TO IMPROVE STUDENTS' MATHEMATICAL CREATIVE THINKING ABILITY IN JUNIOR HIGH SCHOOL
}

\author{
Jenyfah Sebril M. ${ }^{1}$, Bornok Sinaga $^{2}$ \\ ${ }^{1}$ Faculty of Mathematics and natural Sciences, State University of Medan \\ email: jenyfahmanurung@gmail.com \\ ${ }^{2}$ Faculty of Mathematics and Natural Science, State University of Medan
}

\begin{abstract}
The aim of this research is to improve students' mathematical creative thinking ability in the classroom taught using Problem Based Learning (PBL). The design of this research is Classroom Action Research (CAR). The object of this research is the implementation of PBL model. Thesubject of this research is all students in class VIII-A SMP Negeri 4Balige academic year 2017/1018 consist of 32 students. The result of this research are: (1) The number of students who reach category completed for MCTA test in cycle I are 8 persons with percentage of completeness is $25 \%$, students not completed are 24 persons with percentage of completeness is 75\% and the score of MCTA reached is 1,97 in low criteria, (2) The number of students who reach category completed for MCTA test in cycle II are 25 persons with percentage of completeness is $78,125 \%$, students not completed are 7 persons with percentage of completeness is $21,875 \%$ and the score of MCTA reached is 2,81 in high criteria (3) Learning by implemented PBL model could make the students' activity was good category in learning, and (4) Learning by implemented PBL model can improve students' mathematical creative thinking ability.
\end{abstract}

Keywords: Mathematical Creative Thinking (MCTA), Problem Based Learning (PBL)

\section{BACKGROUND}

Mathematics is an important science but in fact mathematics lessons are less desirable, feared, and boring for students. This can be seen from the students' weak math skills. One of the weaknesses among students is the weakness of students in solving math problems. Where students complain and find difficulties in solving problems in math so that students look less able to solve math problems (Novriani and Surya, 2017)
In educational institution the word 'creative' is often used. As educators or learners, we have had experiences with creative writing. Teacher supplies flourish with collections of creative activities or books on creative education of various subjects. Such sources often present attractive and pleasant classroom experiences without tackling the primary questions: What is creativity? Where does it originate? What experiences or circumstances permit individuals to become more creative? Creativity is one product of

Jenyfah Sebril M. ,Bornok Sinaga. The Implementation of Problem Based Learning (PBL) Model to Improve Students' Mathematical Creative Thinking Ability in Junior High School. Jurnal Inspiratif, Vol. 4, No. 2 Agustus 2018 
creative thinking. Nowadays creative thinking is a problem that is often found in students at school.Without information on these more basic issues it is complicated for any teacher to create good quality decisions on classroom practices that might promote creativity in students, though group of activities can be useful.

Based on Silver's opinion, creative thinking ability can be identified by three indicators. First of all, fluency refers to the numberof ideas generated in response to a prompt (Silver in Maharani, 2014). Fluency being able to generate a large number of ideas or responses and to make a deliberate effort to continue to generate alternatives even when you are satisfied with what you have. Maharani (2014:123) stated that fluency includes solve the problem and give a lot of answers to the problem or provide many examples or statements related mathematical situation. The second, flexibility to apparent shifts in approaches taken when generating responses to a prompt (Silver in Maharani, 2014).Flexibility being able to generate a variety of ideas and responses, across different categories and to look at things from different points of view.Maharani (2014:123) stated that flexibility includes the ability to use a variety of problemsolving strategies. Another important indicator is originality of the ideas generated in response to a prompt (Silver in Maharani, 2014). Originality being able to get away from the obvious and commonplace to generate novel ideas and responses. Maharani (2014:123) stated that originality includes using strategies that are new, unique, or unusual to solve problem.

The most powerful way to develop creativity in your students is to be a role model. Children develop creativity not when you tell them to, but when you show them. When teaching for creativity, the first rule is to remember that students follow what you do, not what you say. All students have the capacity to be creators and to experience the joy associated with making something new, but first you must give them a strong base for creativity. Let your students know that they possess the ability to meet all of life's challenges their job is to decide how hard they will work to meet the challenges. Teachers can be role models for questioning assumptions. You can show students that what they assume they know, they don't really know.

One of Model is applied in this research is applying a learning method problem based learning (PBL) model is supposed to make student to become responsible for their own learning. Problem solving can be considered as a method of learning in which students are trained to solve problem.

PBL is the most significant innovation in education. Students are given the opportunity to find knowledge for themselves and deliberate with other. PBL encourages students to take an inquisitive and detailed look at all issues, concept and problem within the given problem. PBL model is a learning model based on a number of issues that require authentic investigation that is an investigation that required a real solution from the real issues (Trianto,2011:90). In this learning model, teacher guides students to describe problem solving into learning steps; teacher give example about the using of skill and strategy are needed to the following task can be solved. Teacher creates flexible class condition and oriented for students' investigation effort.

Problem Based Learning and Realistic Mathematics Education have some similarity especially that both of learning model start from the contextual problem that related to the human daily life, so the researcher want to know whether between of both models is better in helping the students to understanding the mathematics especially in solving the problems that always exist in mathematics. 
Based on the research purpose that will be achieved, then formulated indicator of the success in this research are :

a. There are minimum $70 \%$ of students that follow the test, achieve the criteria of creative thinking ability with minimal score 2,51 in predicate $\mathrm{B}+$ or in high criteria of creative thinking ability.

b. Activity levels of students fulfilling the ideal percentage, and fulfilling four of six categories activity within the tolerance limits.

c. Teacher's ability to manage learning in the class minimum in medium category.

\section{RESEARCH METHOD}

Type of this research is Classroom Action Research (CAR), which aims to find out whether the problem-based learning model can improve the students' mathematical creative thinking ability.

This research had been conducted in SMP Negeri 4 Balige located in $\mathrm{Jl}$. Pelajar, Balige, Kec. Toba Samosir, Sumatera Utara and this research had been conducted in odd semester, academic year 2017/2018.
The subject in this study were students from SMP Negeri 4 Balige, taken one class from an existing class as many 30 students, which is class VIII-A. Class had chosen because based on the background of study, the creative thinking ability of student when giving initial test is low.

The object in this research is an effort to improve students' ability to think creatively by applying problem based learning model on plane Geometry.

\section{RESULT AND DISCUSSION}

\section{Cycle I}

a) Observation Result of Teacher's Ability

Observation result of teacher's activity in cycle I: 
Table 1. Observation Result of Teacher's in Activity in Cycle I

\begin{tabular}{|c|l|c|c|c|}
\hline \multirow{2}{*}{ No. } & \multicolumn{1}{|c|}{ Indicators } & \multicolumn{2}{c|}{ Meeting } & \multirow{2}{*}{ Average } \\
\cline { 3 - 4 } & & I & II & \\
\hline 1 & Skill to Open Learning & 4 & 4 & 4 \\
\hline 2 & Phase I: Orientation of students to the problem & 3 & 4 & 3,5 \\
\hline 3 & Phase II: Organizing student to learn & 3 & 4 & 3,5 \\
\hline 4 & Phase III: Guiding individual and group inquiry & 3 & 3,5 & 3,25 \\
\hline 5 & Phase IV: Developing and presenting the work & 3,5 & 3,7 & 3,6 \\
\hline 6 & $\begin{array}{l}\text { Phase V: Analyze and evaluate the problem solving } \\
\text { process }\end{array}$ & 3,5 & 3,5 & 3,5 \\
\hline 7 & Efficiency using of time & 3,5 & 4 & 3,75 \\
\hline 8 & Skill to close learning & 4 & 4 & 4 \\
\hline \multicolumn{2}{r}{ Total } & $\mathbf{2 7 , 5}$ & $\mathbf{3 0 , 7}$ & $\mathbf{2 9 , 1}$ \\
\hline & $\mathbf{3 R}$ & & $\mathbf{3 , 8 3}$ & $\mathbf{3 , 6 3}$ \\
\hline
\end{tabular}

Scores obtained from observer is converted in the form of percent, namely:

$$
S R=\frac{\text { Sum of Score }}{\text { The Number of Assesment Aspects }}
$$

Based on the observation data in the table above, known that the average score of teacher's activity towards problem based learning model approach is 3,63 with referenced to the criteria that have been defined as follows:

$$
1 \leq \mathrm{SR}<2 \quad: \mathrm{Bad}
$$

$$
\begin{array}{ll}
2<\mathrm{SR}<3 & \text { : Deficient } \\
3<\mathrm{SR}<4 & : \text { Medium } \\
\mathrm{SR}=4 & \text { : Good }
\end{array}
$$

It can be concluded that teacher's activity in carried out the process of problem based learning at cycle $\mathrm{I}$ is medium.

\section{b) Observations Result of Students' Activity}

Students' observation result in cycle I is presented in the following table: 
Table 2.Observation Result of Students' Activity in Cycle I

\begin{tabular}{|c|c|c|c|c|c|}
\hline \multirow[t]{2}{*}{ No. } & \multirow[t]{2}{*}{$\begin{array}{l}\text { Category of } \\
\text { Observation }\end{array}$} & \multicolumn{2}{|c|}{$\begin{array}{c}\text { Students' Activity } \\
\text { Every Meetings } \\
(\%)\end{array}$} & \multirow[t]{2}{*}{$\begin{array}{c}\text { Average } \\
(\%)\end{array}$} & \multirow[t]{2}{*}{ Tolerance Limit } \\
\hline & & I & II & & \\
\hline 1 & $\begin{array}{l}\text { Listening/paying } \\
\text { attention teacher's } \\
\text { explaining }\end{array}$ & $18,75 \%$ & $14,06 \%$ & $16,40 \%$ & $10 \% \leq \mathrm{PTI} \leq 20 \%$ \\
\hline 2 & $\begin{array}{lr}\text { Reading } & \text { book or } \\
\text { other } & \text { relevant } \\
\text { sources } & \end{array}$ & $12,50 \%$ & $20,31 \%$ & $16,40 \%$ & $5 \% \leq \mathrm{PTI} \leq 15 \%$ \\
\hline 3 & $\begin{array}{l}\text { Writing teacher's } \\
\text { explaining, noting } \\
\text { from book or } \\
\text { friends, finishing } \\
\text { problem, concluding } \\
\text { result of group. }\end{array}$ & $25 \%$ & $29,68 \%$ & $27,34 \%$ & $25 \% \leq \mathrm{PTI} \leq 35 \%$ \\
\hline 4 & $\begin{array}{l}\text { Discussing/asking } \\
\text { between student with } \\
\text { teacher or between } \\
\text { student with student. }\end{array}$ & $29,68 \%$ & $21,87 \%$ & $25,78 \%$ & $25 \% \leq \mathrm{PTI} \leq 35 \%$ \\
\hline 5 & $\begin{array}{l}\text { Presenting result of } \\
\text { group. }\end{array}$ & $14,06 \%$ & $4,68 \%$ & $9,37 \%$ & $10 \% \leq \mathrm{PTI} \leq 20 \%$ \\
\hline 6 & $\begin{array}{l}\text { Student's action that } \\
\text { is not relevant with } \\
\text { learning and } \\
\text { teaching activity. }\end{array}$ & $0 \%$ & $9,37 \%$ & $4,68 \%$ & $0 \% \leq \mathrm{PTI} \leq 5 \%$ \\
\hline
\end{tabular}

From the table of ideal time of students activity in cycle I above, can be seen that the activity of students who meet specified to the tolerance limits only categories 1, 3, 4 and 6 with the percentage of $74,20 \%$. Thus in terms of the percentage of the time of students' activity as planned, it was concluded that this study will be continued to the next cycle.

\section{c) Creative Thinking Ability Test 1}

Based on the scores of students' answer obtained from students' creative thinking ability test, can described that the level of students' creative thinking ability and students' mastery learning as follows Students follow creative thinking ability test
1 in the end of cycle 1 after attending the learning as many as 2 meetings. Problem is given by 5 questions in essay form, with a maximum score for each item are 18 points. These points are allocated for each creative thinking indicator in accordance with the lattice of problems. The four indicators of creative thinking are Fluency, Flexibility, and Originality. From four indicators of the creative thinking can be seen where the indicator is more controlled by the student in completing the creative thinking ability test, as shown in the table and diagram below. 
Table 3. The Percentage of Completeness for Each Indicator in Cycle I

\begin{tabular}{|c|c|c|}
\hline Indicator & Number of Students & Percentage \\
\hline Fluency & 11 & $34,375 \%$ \\
\hline Flexibility & 6 & $18,75 \%$ \\
\hline Originality & 2 & $6,25 \%$ \\
\hline
\end{tabular}

Overall results of creative thinking ability test 1 quantitatively can be seen in the following table.

Table 4. Result of MCTA Test in Cycle I

\begin{tabular}{|c|c|c|c|c|c|}
\hline Num & Score & Predicate & Criteria & Total & Percentage \\
\hline \multirow{2}{*}{1} & $3.85<$ score $\leq 4.00$ & A & \multirow{2}{*}{ Very High } & 0 & $0 \%$ \\
\hline & $3.51<$ score $\leq 3.84$ & A- & & 0 & $0 \%$ \\
\hline \multirow{3}{*}{2} & $3.18<$ score $\leq 3.50$ & $\mathrm{~B}+$ & \multirow{3}{*}{ High } & 0 & $0 \%$ \\
\hline & $2.85<$ score $\leq 3.17$ & $\mathrm{~B}$ & & 2 & $6,25 \%$ \\
\hline & $2.51<$ score $\leq 2.84$ & B- & & 6 & $18,75 \%$ \\
\hline \multirow{3}{*}{3} & $2.18<$ score $\leq 2.50$ & $\mathrm{C}+$ & \multirow{3}{*}{ Medium } & 4 & $12,50 \%$ \\
\hline & $1.85<$ score $\leq 2.17$ & $\mathrm{C}$ & & 7 & $21,875 \%$ \\
\hline & $1.51<$ score $\leq 1.84$ & $\mathrm{C}-$ & & 5 & $15,625 \%$ \\
\hline \multirow{2}{*}{4} & $1.18<$ score $\leq 1.50$ & D+ & \multirow{2}{*}{ Low } & 5 & $15,625 \%$ \\
\hline & $1.00<$ score $\leq 1.17$ & D- & & 1 & $3,125 \%$ \\
\hline 5 & $0.00 \leq$ score $\leq 0.99$ & $E$ & Very Low & 2 & $6,25 \%$ \\
\hline \multicolumn{4}{|c|}{ Total } & 32 & $100 \%$ \\
\hline
\end{tabular}

Based on the table above, the number of students who received score $\geq 2,51$ (minimum in High criteria) is 8 from
32 students, or same with $25 \%$ where there is no student got very high predicate, they got high predicate

Table 5. The Percentage of Completeness of MCTA Test in Cycle I

\begin{tabular}{|c|c|c|c|}
\hline SMCTA & Number of Students & Percentage & Category \\
\hline$\geq 2,51$ & 8 & $25 \%$ & Completed \\
\hline$<2,51$ & 24 & $75 \%$ & Not Completed \\
\hline
\end{tabular}

From the result of students' creative thinking ability test in Cycle I after the implementation of problem based learning model, the classical completeness of students in cycle I is $25 \%$ while when referring to chapter III criteria set at least $70 \%$ of students must have a level of creative thinking ability minimal in category High $(\geq 2,51)$.

2. Cycle II

a) Observation Result of Teacher's Ability

Observation result of teacher's activity in cycle II: 
Table 6. Observation Result of Teacher's in Activity in Cycle II

\begin{tabular}{|c|c|c|c|c|}
\hline \multirow{2}{*}{ No. } & \multirow{2}{*}{ Indicators } & \multicolumn{2}{|c|}{ Meeting } & \multirow{2}{*}{ Average } \\
\hline & & $\mathbf{I}$ & II & \\
\hline 1 & Skill to Open Learning & 4 & 4 & 4 \\
\hline 2 & Phase I: Orientation of students to the problem & 3 & 4 & 3,5 \\
\hline 3 & Phase II: Organizing student to learn & 4 & 4 & 4 \\
\hline 4 & Phase III: Guiding individual and group inquiry & 3 & 4 & 3,5 \\
\hline 5 & Phase IV: Developing and presenting the work & 4 & 4 & 4 \\
\hline \multirow{2}{*}{ No. } & \multirow{2}{*}{ Indicators } & \multicolumn{2}{|c|}{ Meeting } & \multirow{2}{*}{ Average } \\
\hline & & $\mathbf{I}$ & II & \\
\hline 6 & $\begin{array}{l}\text { Phase V: Analyze and evaluate the problem solving } \\
\text { process }\end{array}$ & 3,5 & 4 & 3,75 \\
\hline 7 & Efficiency using of time & 4 & 4 & 4 \\
\hline 8 & Skill to close learning & 4 & 4 & 4 \\
\hline & Total & 29,5 & 32 & 30,75 \\
\hline & SR & 3,68 & 4 & 3,84 \\
\hline
\end{tabular}

Based on the observation data in the table above, known that the average score of teacher's activity towards problem based learning model approach is 3,84 . It can be concluded that teacher's activity in carried out the process of problem based learning at cycle I is medium.

\section{b) Observations Result of Students' Activity}

Students' observation result in cycle I is presented in the following table: 
Table 7. Observation Result of Students' Activity in Cycle II

\begin{tabular}{|c|c|c|c|c|c|}
\hline \multirow[t]{2}{*}{ No. } & \multirow[t]{2}{*}{$\begin{array}{l}\text { Category of } \\
\text { Observation }\end{array}$} & \multicolumn{2}{|c|}{$\begin{array}{c}\text { Students' Activity } \\
\text { Every Meetings } \\
(\%)\end{array}$} & \multirow[t]{2}{*}{$\begin{array}{c}\text { Average } \\
(\%)\end{array}$} & \multirow[t]{2}{*}{ Tolerance Limit } \\
\hline & & I & II & & \\
\hline 1 & $\begin{array}{l}\text { Listening/paying } \\
\text { attention teacher's } \\
\text { explaining }\end{array}$ & $21,87 \%$ & $17,18 \%$ & $19,53 \%$ & $10 \% \leq \mathrm{PTI} \leq 20 \%$ \\
\hline 2 & $\begin{array}{lr}\text { Reading } & \text { book or } \\
\text { other } & \text { relevant } \\
\text { sources } & \end{array}$ & $15,62 \%$ & $14,06 \%$ & $14,84 \%$ & $5 \% \leq \mathrm{PTI} \leq 15 \%$ \\
\hline 3 & $\begin{array}{l}\text { Writing teacher's } \\
\text { explaining, noting } \\
\text { from book or } \\
\text { friends, finishing } \\
\text { problem, concluding } \\
\text { result of group. }\end{array}$ & $29,68 \%$ & $25 \%$ & $27,34 \%$ & $25 \% \leq \mathrm{PTI} \leq 35 \%$ \\
\hline 4 & $\begin{array}{l}\text { Discussing/asking } \\
\text { between students } \\
\text { with teacher or } \\
\text { between student with } \\
\text { student. }\end{array}$ & $25 \%$ & $28,12 \%$ & $26,56 \%$ & $25 \% \leq \mathrm{PTI} \leq 35 \%$ \\
\hline 5 & $\begin{array}{l}\text { Presenting result of } \\
\text { group. }\end{array}$ & $4,68 \%$ & $15,62 \%$ & $10,16 \%$ & $10 \% \leq \mathrm{PTI} \leq 20 \%$ \\
\hline 6 & $\begin{array}{l}\text { Student's action that } \\
\text { is not relevant with } \\
\text { learning and } \\
\text { teaching activity. }\end{array}$ & $3,12 \%$ & $1,56 \%$ & $2,34 \%$ & $0 \% \leq \mathrm{PTI} \leq 5 \%$ \\
\hline
\end{tabular}

Furthermore, the average percentage of ideal student activity for each category has been based on the criteria for achieving the ideal percentage of time specified in Chapter III. It can be concluded that the ideal time percentage of student activity in the interval is determined tolerance.

\section{c) Creative Thinking Ability Test 2}

From the three indicators of creative thinking ability, the indicator that gives the biggest contribution in completing creative thinking ability of students can be seen in the following table: 
Table 8. The Percentage of Completeness for Each Indicator in Cycle II

\begin{tabular}{|c|c|c|}
\hline Indicator & Number of Students & Percentage \\
\hline Fluency & 32 & $100 \%$ \\
\hline Flexibility & 18 & $56,25 \%$ \\
\hline Originality & 14 & $43,75 \%$ \\
\hline
\end{tabular}

Overall the result of creative thinking ability test in Cycle II

quantitatively can be seen in the following table:

Table 9. Result of MCTA Test in Cycle II

\begin{tabular}{|c|c|c|c|c|c|}
\hline Num & Score & Predicate & Criteria & Total & Percentage \\
\hline \multirow{2}{*}{1} & $3.85<$ score $\leq 4.00$ & A & \multirow{2}{*}{ Very High } & 0 & $0 \%$ \\
\hline & $3.51<$ score $\leq 3.84$ & A- & & 1 & $3,125 \%$ \\
\hline \multirow{3}{*}{2} & $3.18<$ score $\leq 3.50$ & $\mathrm{~B}+$ & \multirow{3}{*}{ High } & 5 & $15,625 \%$ \\
\hline & $2.85<$ score $\leq 3.17$ & $\mathrm{~B}$ & & 10 & $31,25 \%$ \\
\hline & $2.51<$ score $\leq 2.84$ & B- & & 9 & $28,125 \% \%$ \\
\hline \multirow{3}{*}{3} & $2.18<$ score $\leq 2.50$ & $\mathrm{C}+$ & \multirow{3}{*}{ Medium } & 2 & $6,25 \%$ \\
\hline & $1.85<$ score $\leq 2.17$ & $\mathrm{C}$ & & 4 & $12,5 \%$ \\
\hline & $1.51<$ score $\leq 1.84$ & $\mathrm{C}-$ & & 1 & $3,125 \%$ \\
\hline \multirow{2}{*}{4} & $1.18<$ score $\leq 1.50$ & $\mathrm{D}+$ & \multirow{2}{*}{ Low } & 0 & $0 \%$ \\
\hline & $1.00<$ score $\leq 1.17$ & D- & & 0 & $0 \%$ \\
\hline 5 & $0.00 \leq$ score $\leq 0.99$ & $\mathrm{E}$ & Very Low & 0 & $0 \%$ \\
\hline \multicolumn{4}{|c|}{ Total } & 32 & $100 \%$ \\
\hline
\end{tabular}

Based on the table above, the number of students who received score $\geq 2,51$ (minimum in High criteria) is 23 from 32 students, or same with $71,875 \%$ where there the number of student who got very high predicate is 0 person and high predicate 23 persons.

Table 10.The Percentage of Completeness of MCTA Test in Cycle II

\begin{tabular}{|c|c|c|c|}
\hline SMCTA & Number of Students & Percentage & Category \\
\hline$\geq 2,51$ & 25 & $78,125 \%$ & Completed \\
\hline$<2,51$ & 7 & $21,875 \%$ & Not Completed \\
\hline
\end{tabular}

There is an improving of MCTA from cycle I to cycle II, if we compare the results. The number of creative students improved from $25 \%$ in cycle $I$ to be $78,125 \%$ in cycle II. So, in classical contained $78,125 \%$ have a minimum level of creative thinking ability in the category high $(\geq 2,51)$. The result had shown achievement of successful indicator where at least $70 \%$ of students have a minimum level of creative thinking ability in category high.

Based on the implementation of the actions taken can be shown a comparison between the results of the implementation in cycle I and cycle II in the following table. 
Table 11. Comparison between Cycle I and Cycle II

\begin{tabular}{|c|c|c|}
\hline Category & Cycle I & Cycle II \\
\hline Completed & 8 & 25 \\
\hline Not Completed & 24 & 7 \\
\hline Percentage of Completeness & $25 \%$ & $78,125 \%$ \\
\hline Teacher's Activity & 3,63 (Medium) & 3,84 (Medium) \\
\hline Students' Activity & Categories 1,3,4 and 6 & All categories \\
\hline
\end{tabular}

Based on table, all indicators of success in this research had been reached. Because students are able to understand the matter through SAS and teacher's explanation. In addition, it also supported by the courage of students to ask to teacher and their friend about things that they did not understand at the time of learning process.
The comparison on the table, there is an improvement between cycle I to cycle II. The gain normalization through cycle I to cycle II was 0,47 . It means the minimum score of indicator of success have been achieved.

Improving of students' creative thinking ability from cycle I to cycle II can be seen in diagram below.

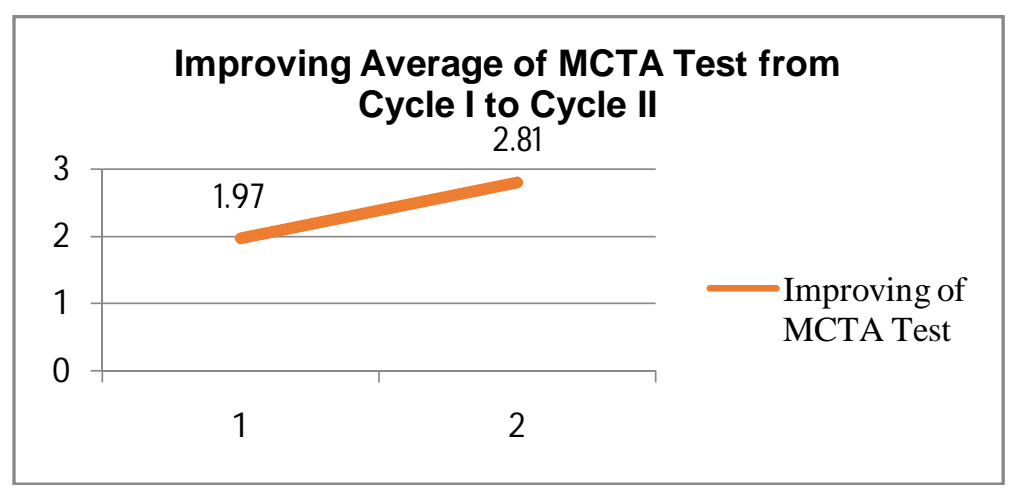

Figure 1. The Diagram of Improving Average of MCTA Test from Cycle I to Cycle II

Based on the result of research that conducted by researcher to improve students' mathematical creative thinking ability by implemented the Problem Based Learning (PBL) model showed that there was increasing of students' mathematical creative thinking ability. This meant that students needed to force the activity in discussion, asked to their friend that understood the material as the first point in mathematics learning using Problem Based Learning (PBL) model.

Action had given in cycle I made the number of students who are able in fluency indicator is $34,375 \%$, the number of students who are able in flexibility indicator is $18,75 \%$, and the number of students who are able in originality indicator is $6,25 \%$. After being accumulated related to scoring rules, the number of students who are able to think creatively in cycle I as many as 8 (25\%) persons from 32 students. Because the number indicator of success is $70 \%$ or minimum score is 2,51, and the number of students who think creatively in cycle I not reach the indicator of success, it meant this research be continued to cycle II. 
Action had given in cycle II made the number of students who are able in fluency indicator is $100 \%$, the number of students who are able in flexibility indicator is $56,25 \%$, and the number of students who are able in originality indicator is $43,75 \%$. After being accumulated related to scoring rules, the number of students who are able to think creatively in cycle II as many as 25 $(78,125 \%)$ persons from 32 students. Because the number indicator of success is $70 \%$ or minimum score is 2,51 , and the number of students who think creatively in cycle II reach the indicator of success, it meant this research had been stopped, but there is an indicator that not reach that score, they are flexibility and originality indicator. Related to Surya, Dermawan, and Syahputra (2017) said that creative thinking viewed as a process that used when an individual bring up a new idea. Saragih and Habeahan (2014) also said creativity is essentially a person's ability to give birth to something new which are relatively different from that already exist previously. So it meant that not all students can reach all indicator especially originality indicator and the improvement of originality indicator from cycle I to cycle II is low.

\section{CONCLUSION AND SUGGESTION}

\section{Conclusion}

Based on the research discussion in the previous chapter can be concluded that the implementation of problem based learning model can improve the students' mathematical creative thinking ability. Action that given in cycle II showed the improved of students' ability, which is students' had reached the indicator of success with the minimum score 2,51 were in cycle I there are 8 or $25 \%$ students who got the minimum score, and in cycle II there are 25 or $78,125 \%$ students who got the minimum score. So the improvement of students between cycle I to cycle II is 17 or $53,125 \%$ students. In this research, gain normalization that reached are 0,47 with gain score 0,414 which is categorized as medium category. It means, this research reached the indicator of success because more than $70 \%$ students reached the minimum score.

In the activity of writing the report, students perform the activities of reasoning through discussion, which is discussing the results of experiments that have been done (Simamora, et al, 2017)

The level of students' activity by implemented Problem Based Learning model have been fulfill the ideal percentage, fulfill four of six categories activity and determined tolerance.

\section{Suggestions}

Based on the research results, the researcher suggests some suggestion as follows:

1. The implementation of problem based learning model in learning process, it is expected that teacher gives problems on SAS that can arouse students' enthusiasm, and can be make students' feel challenge to show their ability to find something new related to their knowledge.

2. To implement the problem based learning model, teacher needs a lot of time. So, it is expected that teacher who will implement this learning model have to choose a subject matter topic which possible to teach and prepare the learning tools to maximize the learning outcomes.

3. For action research that will implement, teacher must be has a good prepare about the lesson plan and SAS because those are very important in learning process.

4. In the implementation of problem based learning model, it is expected for 
teacher to share the group evenly and with a small amount so that during the learning process every group is conductive and every individual took part in the group.

5. Teacher activity has a big influence on students learning outcomes, so it is expected teacher can use the time as effectively as possible and as long as student discuss the problem, teacher helps each group equally.

6. For the next researcher, it is expected to choose the other subject matter topic to implement the problem based learning model to improve students' creative thinking ability.

\section{REFERENCES}

Abdurrozak, R., Jayadinata A.K., 'Atun, I. (2016). Pengaruh Model Pembelajaran Terhadap Kemampuan Berpikir Kreatif Siswa. Jurnal Pena Ilmiah, 1(1).

Arikunto, S. 2013. Prosedur Penelitian. Jakarta: Rineka Cipta 2013

Christiansen, E. T., Kuure, L., Mørch, A., \&Lindström, B. (Eds.) (2013).PROBLEM-BASED LEARNING FOR THE 21st CENTURY-New Practices and Learning Environments. (1 ed.) Dermark: Aalborg University Press.

Kadir\& La Masi. (2014). Mathematical Creative Thinking Skills Of Students Junior High School In Kendari City. Innovation and Technology for Mathematics and Mathematics Education Proceeding,ISBN : 978-602-103700-3.

Kanematsu, H. \& D. M. Barry. (2016). Theory of Creativity.Switzerland :
Springer International Publishing Switzerland 2016.

Maharani, H. R. (2014). Creative Thinking In Mathematics: Are We Able To Solve Mathematical Problems In A Variety Of Way?.International Conference on Mathematics, Science, and Education 2014.

Novriani, M. R. and Surya, E.2017. Analysis of Student Difficulties in Mathematics Problem Solving Ability at MTs Swasta IRA Medan. International Journal of Sciences: Basic and Applied Research (IJSBAR). 33(3), 63-75.

Trianto, (2011), Mendesain Model Pembelajaran Inovatif-Progresif, Kencana, Jakarta.

Saragih, S, dan Winnery L. Habeahan. 2014. The Improving of Probem Solving Ability and Students' Creativity Mathematical by Using Problem Based Learning in SMP Negeri 2 Siantar. Journal of Education and Practice,vol. 5, no. 35, page: $123-132$.

Sinaga, Y.D. (2017). Pengaruh Model Problem Based Learning Untuk Meningkatkan Kemampuan Berpikir Kreatif Matematis Siswa. Prosiding Seminar Nasional Tahunan Fakultas Ilmu Sosial Universitas Negeri Medan Tahun 2017, ISSN: 2549-5976

Surya, E., Dermawan, D.A., Syahputra, E. (2017). The Efforts to Improving the Creative Thinking Ability Through Problem-Based Learning of Junior High School Students. International Journal of Novel Research in Education and Learning, 4(2): 2394-9686. 
Wood, D.F. (2003). PubMed CentralProblem Based Learning (journal), BMJ Publishing Group Ltd.

Zhou, M. \& Brown, D. (2014).Educational Learning Theories.Georgia :
Spring.(http://alohamindmath.co $\mathrm{m} / \mathrm{blog} / 10$-reasons-why-we-needmath=www.google.co.id/ accessed on January $12^{\text {th }} 2018$ )

Jenyfah Sebril M. ,Bornok Sinaga. The Implementation of Problem Based Learning (PBL) Model to Improve Students' Mathematical Creative Thinking Ability in Junior High School. Jurnal Inspiratif, Vol. 4, No. 2 Agustus 2018 